\title{
'It is better to herd than be herded': making a living with goats in the Bajío region, Mexico
}

\author{
David Oseguera Montiel ${ }^{1 *}$, Nícola Maria Keilbach Baer ${ }^{2}$, Akke van der Zijpp $^{1}$, Chizu Sato ${ }^{3}$ and Henk Udo ${ }^{1}$
}

\begin{abstract}
Goats are renowned for their resilience in harsh environments and their relatively low investment for maintenance. Goat husbandry is thought to be a tool for poverty alleviation. Empirical evidence of this is scant. This research analysed the role of goat husbandry in supporting the livelihoods of smallholders from the Bajío region in Michoacán, Mexico. The Bajío is renowned for the good cropping potential of the land; smallholder goat husbandry is present too but largely unstudied by scholars and ignored by policy makers. The smallholders in the study area deploy a range of assets, natural, physical, social, human and financial, in goat husbandry. Their goat husbandry is dairy-oriented; it is a source of weekly income and insurance and therefore an alternative to out-migration. Farmers' relatively high social capital allows them to access cheap crop residues and take turns herding flocks. The goat dairy market is controlled by a powerful caramel industry. In turn, the margins smallholders obtain are rather limited. The nutritional value of goat milk is not exploited in their households as it is seen as a 'fever' cause, related to brucellosis. Qualitative and quantitative methodologies are based on the sustainable livelihoods approach linked to actor-oriented approaches. The study revealed smallholders' agency by engaging in goat husbandry to deal with a complex institutional and political context dominated by economic liberalization intertwined with local realities such as the agroecology. We emphasize the importance of these findings in development strategies for small-scale goat husbandry systems.
\end{abstract}

Keywords: Actor-oriented; Ejido; Goat husbandry; Livelihoods approach; Michoacán; Neoliberalism; Smallholders

\section{Background}

Goat husbandry is considered to have great potential to improve the livelihoods of poor people (Sinn et al. 1999; Peacock 2005; De Vries 2008). Compared to cattle, goats are easier to raise in resource-poor households. This is because goats are resilient animals that can cope with relatively low quality feed and scarce water (Morand-Fehr 2005). In the global South, goat husbandry produces more value than single-sided production-economic criteria. Goat husbandry plays a role in financial security, women's empowerment and insurance (Bosman et al. 1997; Dossa et al. 2008). Furthermore, goat husbandry exemplifies smallholders' agency, referring to smallholders' capacity to act and make choices. Smallholders' agency is often in response to an adverse context for smallholders, which in Latin America is partly the result of the neoliberal policies

\footnotetext{
*Correspondence: oseguera.david@gmail.com

'Animal Production Systems Group, Wageningen University, P.O. Box 338, Wageningen $6700 \mathrm{AH}$, the Netherlands

Full list of author information is available at the end of the article
}

promoting free trade, privatization and deregulation, among others.

Under the neoliberal paradigm, Mexican smallholders are portrayed as backward or inefficient and hence the rhetoric that Mexico needs a 'modern' agricultural sector (Toledo 1992). Smallholders are often deemed as the 'nonviable' (Bebbington 1999) and therefore the way forward for neoliberal planners is to intensify and modernize the agricultural sector. For example, in 1992, the Mexican government, arguing that rural smallholders lacked productivity, launched the counter-land reforms that opened the door for seizing 'ejidos' - smallholders' community-owned land, which was about half of the agricultural land until 1991. This policy resulted from the negotiations of the North American Free Trade Agreement (NAFTA) (Schmidt and Gruben 1992). Furthermore, public funds for the smallholder sector, in the form of subsidies and extension services, were withdrawn, and BANRURAL (a farmers' bank) and CONASUPO (an institution to guarantee fair crop market 
prices) were dismantled. Under NAFTA, there has been an unprecedented growth of commercial food corporations with oligopolistic control of food commodities (Ochoa 2013). This context for rural smallholders is further complicated by the unprecedented wave of violent crime often related to drug trafficking (Pereyra 2012). And yet smallholders are still resisting this hostile context. On and off-farm diversification has been their main survival strategy in Latin American countries (Kay 2008).

In Mexico, small-scale goat husbandry is one of these on-farm diversification strategies. Goats can be found across the country (INEGI 2007). Although goat husbandry started during the Spanish colonization in the 16th century, little is known about the role of goat husbandry in contributing to smallholders' livelihoods. It might be a good option particularly among rural poor people to fight poverty which affects approximately half of the Mexican population (CONEVAL 2009). This paper aims to study small-scale goat farmers' agency to make their living in a complex context, by using a sustainable livelihood framework that integrates actor-oriented approaches. We argue that small-scale goat husbandry is functional and well-adapted to the agroecological conditions of the Bajío region, a prosperous cropping area in central Mexico. We also unravel the threats and opportunities involved in small-scale goat husbandry as a livelihood strategy. In the following sections, we present the theoretical framework and methods and the historical background within which goat husbandry currently operates in the region. There follows an in-depth analysis of how goat husbandry has adapted to the local context and contributes to smallholders' livelihoods.

\section{Theoretical framework}

We used the sustainable livelihoods approach (SL) to analyse how smallholder goat farmers generate livelihoods in their specific agroecological and socio-economic context. A livelihood comprises: '[A]ssets...activities and the access to these (mediated by institutions and social relationships) that together determine the living gained by the individual or household' (Ellis 2000, p.10). Assets or capitals for smallholders are natural capital comprising communal land grazing, water and crop land; physical capital comprising tools, machinery, infrastructure (e.g. roads, railway) and livestock; social capital comprising reciprocity, associations, cooperation and trust; human capital comprising people's skills, knowledge, health, education and traditional knowledge transmitted through generations; financial capital comprising money stored in a bank or at home, and credits or loans (Chambers and Conway 1992; DFID 1999; De Haan 2000; Ellis 2000).

Mapping out capitals according to different socioeconomic strata of households can help to identify where pro-poor support can have impact (Bebbington 1999).
Socio-economic strata are often identified on how households themselves define being poor, sometimes in relation to their assets (Kristjanson et al. 2007), however, households' capabilities can be important too in defining well-being by households. Capability refers to being able to eat well, dress, live without shame and have a social life among others (Chambers and Conway 1992). Furthermore, it refers to being able to respond to shocks or stress, but also in being proactive by taking up opportunities to enhance their livelihoods, such as making use of information, collaborating with others, experimenting, and using new resources and services (Chambers and Conway 1992). This study tries to understand the role of goats in terms of households' capitals and capabilities.

Capitals can be converted to other forms of capitals and there are tradeoffs on how capitals are used (DFID 1999). For example, goats, a natural capital, can be used to generate outputs like meat, milk and manure, which are often a source of income (Ellis 2000). Goats are liquid assets to be used in times of cash need, so for smallholders, goats are an insurance (Bosman et al. 1997). Goat management, however, can also lead to the destruction of other capitals. By way of example, in Indonesia, goat manure is a valuable output for cropping by enhancing land fertility, a natural capital, but at the same time, manure is piled up near settlements and pollutes ground water (Budisatria 2006).

Access to capitals is central in understanding livelihoods while reflecting how policies and institutions affect access to capitals is also important (DFID 1999). In access to capitals, politics and power relations play a role. As such, 'a livelihood is organized in arenas of conflicting [and] co-operating actors' (De Haan and Zoomers 2005, p.34). Yet, politics have been overlooked in livelihood studies (Scoones 2009). Politics relate to how macro policies (e.g. neoliberal globalization in Mexico) and power relations among actors affect the access to capitals. In the Mexican rural context, different actors often collide and intertwine (Long 1998). Drawing on these concepts, we postulate that goat husbandry is a livelihood strategy adapted historically to its specific context and that goatkeeping households employ a range of capitals, the access to which is influenced by the context. This refers to the institutional and political context in which goat husbandry is embedded, such as the agroecology and everyday relations of farmers among themselves and with other actors.

\section{Study area}

\section{Agroecological conditions}

The study was conducted in northern villages of Michoacán, a part of the Bajío region which is a relatively large area that encompasses territories of four central states (Michoacán, Guanajuato, Querétaro and Jalisco) of Mexico (Chávez-Torres 2005). The region 
is characterized by plains interrupted by multiple hills and volcanoes. The altitude ranges from 1,000 to $2,000 \mathrm{~m}$ above sea level, rainfall average is $800 \mathrm{~mm}$ and most precipitation is during the summer period (June to October). Ambient temperature averages $20^{\circ} \mathrm{C}$. The Bajío region is a river basin area that has a high crop production potential, with irrigation in some areas. Land is cultivated for maize, sorghum, wheat and now notably cash crops (vegetables and fruits) in greenhouse systems for export to the USA (Chambers et al. 2007). Two main forms of cropping can be found: high-input industrial agriculture and traditional low-input crop production (González-Martínez 1992), a pattern present since colonial times where irrigated wheat was the predominant crop (Chambers et al. 2007). Smallholders cultivate maize, sorghum, wheat, chickpeas on rainfed marginal land as well as on high potential agricultural land, mainly for self-consumption (by humans and animals), but as cash crops too. Besides cropping, smallholders are also engaged in seasonal wage labour, livestock husbandry and temporal migration to the USA. The region has one of the highest rates of out-migration to the USA in the country (Arias and Mummert 1987).

\section{Historic context of goat husbandry in the region}

Goats were introduced by the Spaniards in the 16th century during colonization. In this period, the goat population had an exponential growth, due to the abundance of feed sources, grazing land and crop residues (Braudel 1984). Spaniards seized indigenous peoples' land, which became the 'Haciendas' - huge farms. In the search for more crop land, Spaniards moved to the Bajío region, where goats were used mainly to clear off the vegetation for later land cultivation (Baroni-Boissonas 1990). Then goats became the most prominent livestock species (Rabell 1986). Goat meat was also a food source for mine workers and goat fat was used to make candles for the mines of the region. In the 18th and 19th centuries, when cropping became an important activity in the Bajío, cattle outnumbered goats. This was linked to the development of more sedentary farming systems (Rabell, 1986). Goats were kept in extensive grazing systems and cared for by hacienda workers (Zendejas-Romero 2003).

By the 1930s, some haciendas were dissolved and the land was distributed among smallholders, who were entitled to work a plot of land in a so-called ejido system. Currently in the Bajío region, small-scale goat husbandry based on semi-extensive grazing management is relatively popular, especially in villages of the Chapala lake basin area and the Lerma river. Goat milk is the main input for cajeta - similar to the English caramel. The cajeta industry plants are found in the region. Smallholders keeping goats are colloquially known as chiveros. Goat meat has a local market for a popular dish called birria.

\section{Methodology}

The field work was conducted in two periods: (1) from February to July 2007 and (2) from May 2008 to July 2009. A snowball technique (Biernacki and Waldorf 1981) was used to identify villages where small-scale goat husbandry was present. In the first period, villages of Tanhuato and Ecuandureo municipalities were visited by the field researcher. Semi-structured interviews gave a better understanding of goats' multifunctional roles and farmers' constraints. Smallholders herding their flocks were approached and appointments were made for interviewing. Secondary data was sought to understand the history of goat husbandry in the region. Two cross-sectional surveys were carried out in four villages, Cieneguitas, Los Charcos, San José de Vargas and Tinaja de Vargas from the municipality of Tanhuato (Figure 1). The first survey was used to characterize smallholders' livelihoods assets by their socioeconomic strata. In this survey we also investigated how goat husbandry was valued by households; this included identification of the different functions represented in goat husbandry and small holders' other strategies. This study was approved by the Wageningen Institute of Animal Science, Wageningen, the Netherlands.

Goat keepers were subdivided into three wealth groups: 'poor' , 'medium' and 'better-off'. In conjunction with an NGO employee who had been working directly with goat farmers to control brucellosis, a key informant was identified within each village to help sort fellow villagers into the wealth strata. From a census by the NGO, a list was obtained with names of the head of the household and his or her number of goats. The second survey aimed to understand the views of goat farmers' neighbours about goat husbandry. A random sample of 145 households was interviewed using a questionnaire with closed questions.

The second part of the study involved a longitudinal survey and qualitative methods. The purpose of the survey was to calculate the gross margins of goat husbandry and crop production. Data about inputs and outputs of crop and goat production over the year were obtained from 18 farmers. Farmers recorded the information in notebooks, which were then collected on four occasions throughout the year. Gross margins were calculated as the difference between the outputs, such as crops, milk, goat kids and the inputs, for example, fertilizers, sprays, feed, vaccines, wormers and antibiotics. The contribution of goat husbandry and cropping to cover a family's basic necessities (e.g. food, housing, health, education) was evaluated by comparing gross margins with the poverty threshold in rural Mexico which is 15,384 Mexican pesos (MX\$) (1 MX\$ = 0.08 USD, source: Banixco 2012) per year per capita (CONEVAL 2009). Milk price was also compared to inflation in Mexico from 2006 to 2008.

Qualitative methods involved ethnographic observations in households, milking sites, grazing areas, farmers' meetings and milk collection. We also used rural appraisal 


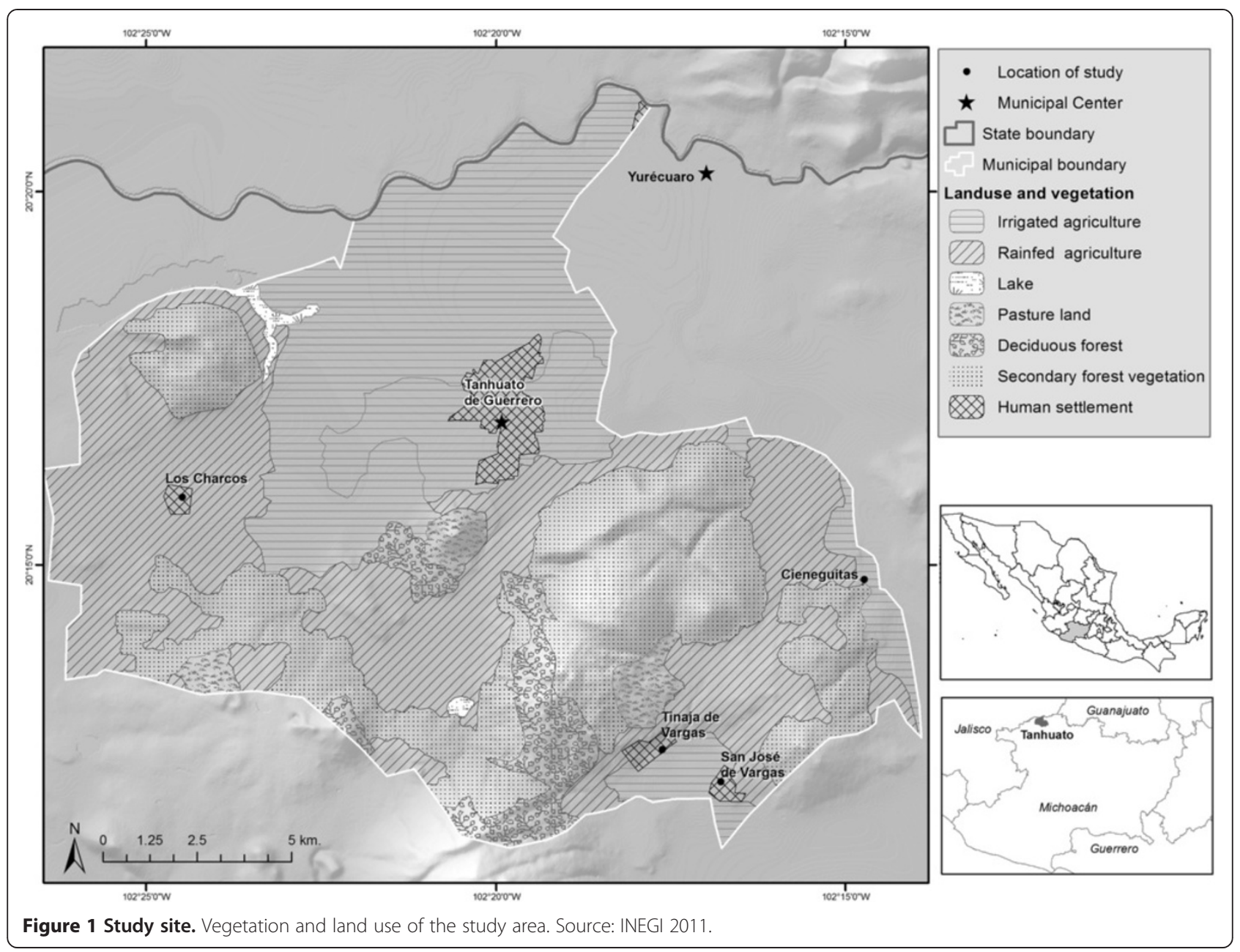

techniques such as group discussions about goat husbandry versus temporal migration to the USA (three group discussions), mapping and transects (three completed), semi-structured interviews with farmers $(n=19)$ and other stakeholders $(n=10)$, and informal talks among smallholders and stakeholders.

Quantitative data was described with R ( $\mathrm{R}$ Core Team 2012) and ggplot2 was used for graphs (Wickham 2009). Interviews were generally audio-recorded, or else notes were taken. Audio-recorded interviews (ranging from 1 to $2 \mathrm{~h}$ ) were fully transcribed in Spanish. Qualitative analysis was done by (1) coding material, (2) identifying themes and by (3) describing and exploring themes. We used Weft QDA for coding (Fenton 2006).

\section{Results}

\section{Capital status of different groups of smallholder farmers}

Figure 2 shows the distribution of land, the main natural capital, in the four villages. Most of the cultivated land is used for growing maize and sorghum; the latter is more common in villages of San José de Vargas and Tinaja de Vargas (plot B). Some plots have irrigation systems which allow farmers to cultivate the land twice per year with a rainfed crop - often maize or sorghum - and an irrigated crop (often wheat) in the dry season. The communal non-cultivated land is mostly shrub, which is used mainly to graze goat flocks during the rainy season.

Table 1 shows the distribution of some of the capitals across the wealth groups. Better-off goat keepers had on average 15 ha of cropland (first and third interquartiles (IQ) 11 to 21). Most of this land was of higher quality, located in the valleys, leveled and some plots had irrigation. Most of these farmers had large flocks, on average 131 goats (80 to $154 \mathrm{IQ}$ ). These farmers invariably had a truck and a tractor.

The poor and the medium wealth groups had less of the above capitals. Poor households had on average 37 goats (22 to 45 IQ). Two-thirds of the households in the poor group owned 2 ha of land on average (1 to 2.5 IQ). Poor households' crop land was often in communal areas and was known as ecuaros, which were plots of approximately 1 ha in the edges of the hills. The medium wealth group had on average 90 goats (32 to 123 IQ). They owned relatively better crop land than the poor and on average 


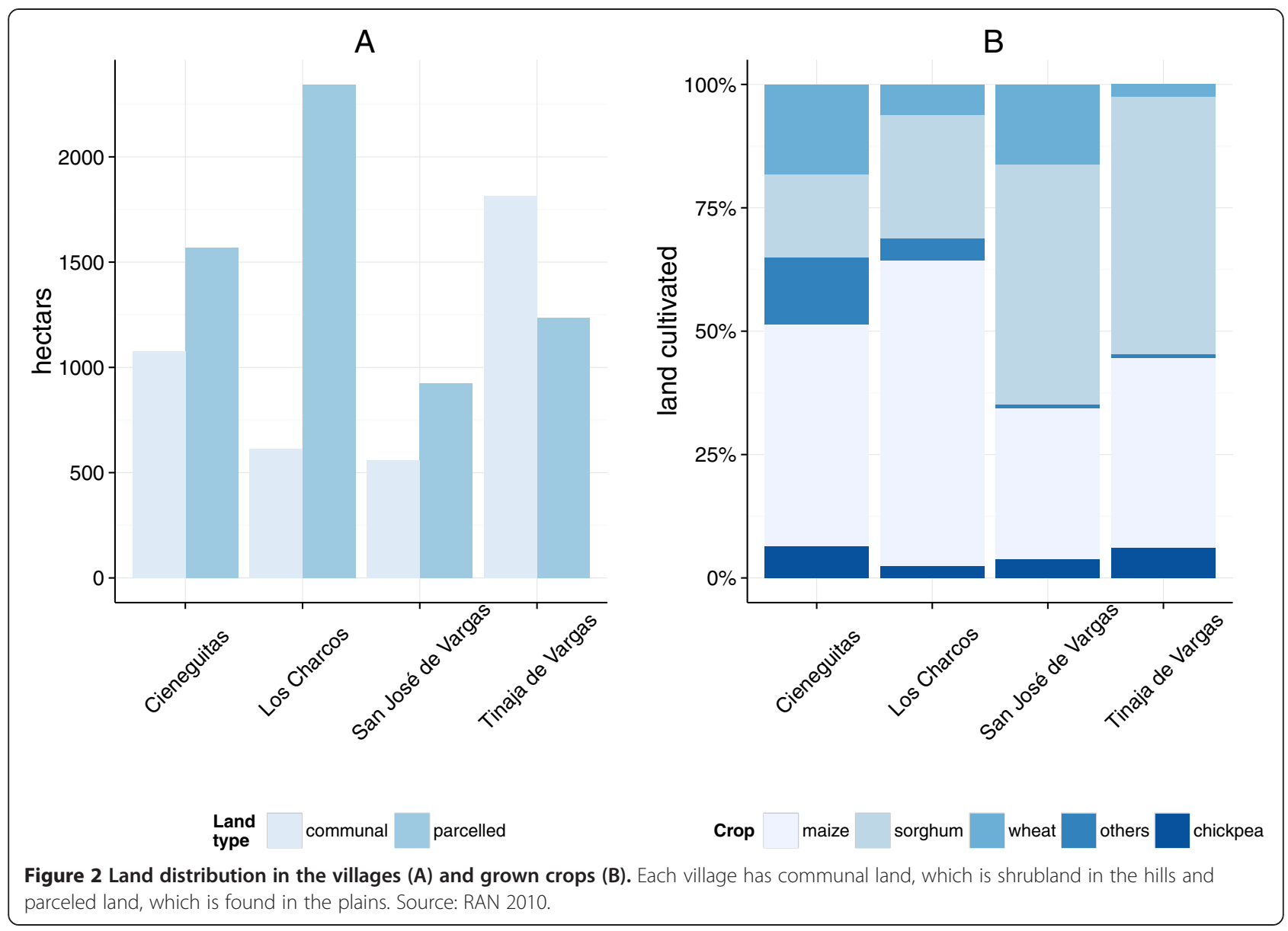

Table 1 Descriptive statistics of farmers' assets and household characteristics according to their strata

\begin{tabular}{lccccc}
\hline & Median & IQ & Mean & SD & N \\
\hline Land (ha) & & & & & \\
Poor & 2.0 & 1.0 to 2.5 & 2.0 & 1.2 & 14 \\
Medium & 5.0 & 4.0 to 7.0 & 5.8 & 2.6 & 21 \\
Better-off & 15.5 & 11.0 to 21.0 & 15.8 & 9.2 & 8 \\
Goats ( $n$ ) & & & & & \\
Poor & 30 & 22 to 45 & 37 & 21 & 17 \\
Medium & 70 & 32 to 123 & 91 & 83 & 23 \\
Better-off & 107 & 80 to 154 & 131 & 87 & 8 \\
Household size (n) & & & & & \\
Poor & 5 & 3 to 6 & 5 & 2 & 17 \\
Medium & 5 & 4 to 6 & 5 & 2 & 23 \\
Better-off & 4 & 4 to 6 & 5 & 2 & 8 \\
Age household head (years) & & & & \\
Poor & 49.5 & 44.5 to 54.0 & 50.0 & 12.1 & 16 \\
Medium & 51.0 & 39.0 to 64.0 & 50.2 & 13.7 & 23 \\
Better-off & 39.5 & 36.3 to 58.3 & 45.6 & 16.7 & 8 \\
\hline
\end{tabular}

$\mathrm{IQ}$, interquartile range; $\mathrm{SD}$, standard deviation; $N$ number of observations. they owned 6 ha of land (4 to 7 IQ). There were however, landless farmers in these two groups too $(n=3$ in poor and $n=2$ in medium). Two-thirds of medium farmers had a truck and $15 \%$ had a tractor, whereas only a quarter of poor farmers had a truck and only one poor farmer had a tractor.

There were no differences among wealth groups in household size or age of the household head (Table 1). Despite the similar size of the households, health status, migration and age of children played a role determining the wealth stratum of the household. Households were classified as poor when the head of the household (a man) was unfit for physical work due to illness. For example, one household deemed as poor had three children in their teens, approximately 0.75 ha of crop land and 45 goats. The man, however, was incapable of doing any work as he was in a wheelchair. Relatively, young married couples with infants, absence of the man (head) due to migration to the USA and being hired as labourers were other reasons given to classify households in the poor group. Two-thirds of the households reported having more than 10 years of experience in goat husbandry, regardless of their socio-economic group. 
There was a range of social capital forms among households. It was remarkable the companionship that derives in sharing responsibilities for herding goats. Some households also engaged in entrepreneurial activities such as growing alfalfa (one farmer with irrigated land and another with financial assets). In one of the villages, farmers constantly communicated to help each other during herding, often to find lost animals or share news, using walkie-talkies. The form of social capital also differed among the wealth groups. The medium and better-off groups for example made strong ties with some of the personnel from the NGOs. An NGO person could be invited to have lunch at their houses. In return, these households could have their flocks vaccinated first.

There was a history of rivalries between families of two villages which weakened social capital at community level. This rivalry had led to deaths in both villages. During the field study for example, farmers from one of the villages reported they felt oppressed by an extended family from the neighbouring village. These farmers were often insulted by this family. 'They also come at nights to dare our children', the farmers reported. For some farmers, the situation was unbearable and they fled because of fear of violence against them or because of direct death threats. Two extended families migrated to nearby villages together with their goats, but were unable to harvest their crops any more. Three other households sold their flocks and tried to make their way elsewhere.

The wealth ranking exercise showed how goat farmers perceived their well-being. In general, farmers considered themselves to be better-off compared to those having no goats (physical capital). Figure 3 shows that goats were not just a source of income. Security was also important. Having goats was a guarantee of access to credits in their village. '[W]ith a small flock one can defend better than one who owns nothing...being a goat farmer you always have one or two pesos in your pocket'. 'You are what you have, if you have goats you can get credits, if you only have land you will not get them. [The logic of the lender is].. [a farmer] will not sell land to pay but he will sell goats' (farmer, San José de Vargas). In the group discussions, it was stated that having a flock was also a way to be your own boss and not to be fully dependent on being a hired labourer 'mas vale arrear que ser arreado' (it is better to herd than be herded).

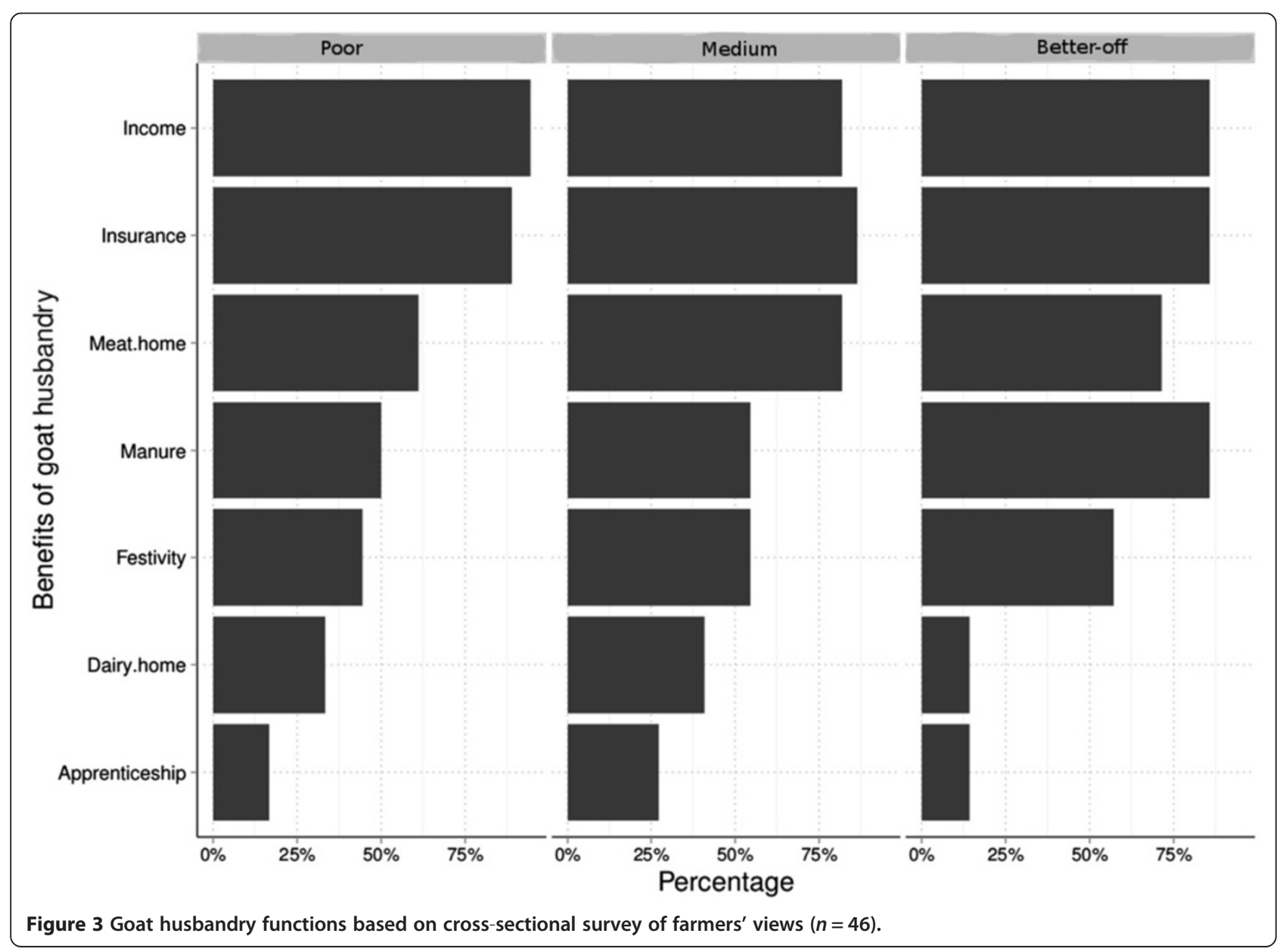


Furthermore some job offers were not acceptable. Farmers reported that they were hired to apply a lot of chemicals in cropping (e.g. pesticides and herbicides), they have long workdays (15 hours) and wages were not good either. Farmers also benefit by having birria (the local goat meat dish) at their disposal. About $11 \%$ of the male goat kids were for self-consumption. Farmers could also please friends or relatives with a birria dish for special occasions such as in children's graduations from primary or secondary school. Goat male kids were also given as gifts; about $14 \%$ of the male goat kids were given to friends or to neighbours to thank them for allowing the goats to graze their crop residues.

For some senior farmers, goat husbandry was the base for accumulating other capitals (i.e. land and cattle). The best example of this was a handful of extended family households who had managed to consolidate relatively large flocks $\geq 400$ equal to about 30 goats per capita. Farmers reported that their parents had started with just a handful of goats. Among farmers who managed to consolidate large flocks, especially middle-aged farmers, migration to the USA was not considered an option. One said 'I am happier here with my goats' (farmer, San
José de Vargas). Young men however, with a small flock (<15 goats) and little land of low crop production potential were relatively eager to migrate.

\section{Livelihood strategies portfolio}

Figure 4 shows that households engaged in a range of activities to optimize their cash income, food selfsufficiency and risk management. The range of activities tended to be wider for households in medium and better-off groups. Cropping was the most frequently reported activity across the three wealth strata of households. External inputs were fertilizers, seeds, sprays, hired labour, diesel, machine hiring and transportation. Therefore, households in particular farmers in medium and better-off groups sought to get credits to cultivate land. Households grew for the market and for home consumption. In general, only households in the better-off and medium groups could grow for the market (sorghum and maize). Land with less cropping potential, which was cultivated with fewer external inputs, was often used to grow maize for home consumption by poor households, which shows the importance of maize for food selfsufficiency in poor households. Households with irrigated

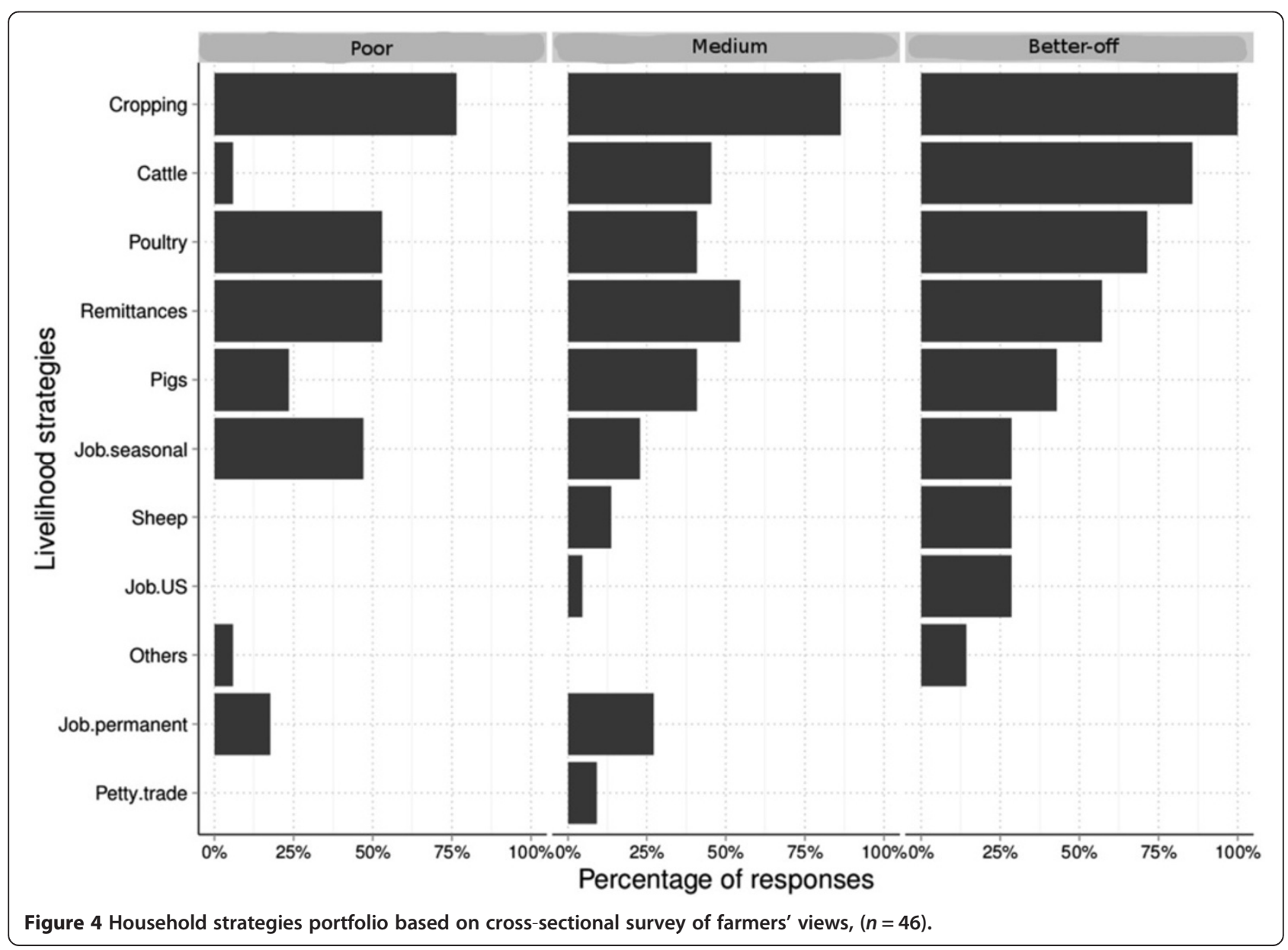


land cultivated wheat and alfalfa. Chickpeas were also cultivated and used as fodder for goats. Farmers cultivated chickpeas in plots that have some residual humidity, and often shortly after, they noticed that their first crop (e.g. maize) would not give a good harvest when rains were delayed, which shows how farmers manage risks. Another risk management strategy was to cultivate sorghum rather than maize, because sorghum was perceived by farmers as more drought resistant than maize. Middle and better-off farmers cropped more land than they owned because they hired or borrowed crop land. In contrast, poor households could not always crop their own plots, because of lack of cash to get inputs or because of lack of male labour in the household.

Among households from lower and medium strata keeping one or two sows to sell piglets was common, especially in the village Los Charcos. Cattle keeping was negligible for households in the lower wealth strata compared to households in the medium and in the better-off groups. Better-off households keeping cattle owned relatively large cattle herds of about 100 head, whereas the few poor households with cattle had only one or two animals.

Household income was often complemented with remittances from the USA, agricultural wages and non-agricultural salaries from the nearby towns (i.e. Zamora and Tanhuato). Farmers reported that remittances were used to get inputs for the flock such as feed.

Women were engaged in specific income-generating activities. Women from the medium group were selling chicken parts and making cheese. Making prayer beads and other religious crafts by sewing was common among women from poor households. Women in the poor and medium groups were also engaged in seasonal work, such as harvesting vegetables and fruits, and in permanent jobs, such as packing strawberries for the frozen fruit industry of Zamora.

\section{Goat husbandry as pastoralism}

In general, goat husbandry in the Bajío region can be characterized as a pastoral activity. Farmers were knowledgeable about the grazing behaviour of goats and their adaptation to the environment. Goats were herded to graze crops, crop residues and native vegetation in communal land and roadsides. Farmers herded their goats to graze native grasses, fodder trees and shrubs in the hills of communal land and roadsides during the rainy season (July to October), which is a period when goats were dried off from milking (Figure 5). The dry season lasts from mid October to mid June. In the dry season, goats were herded to graze crop residues of rainfed crop of maize, sorghum, chickpeas and irrigated crops of wheat. Farmers also herd their flocks to directly graze crops, mostly sorghum and chickpeas. Some other farmers kept their harvest to feed their goats in periods of poor forage availability. There were not many maize and sorghum residues left by the end of March. At this time of the year, most farmers stopped the grazing system and changed to stall-feeding, based on stored crop residues, crops and purchased forage and concentrates. Some farmers continued with grazing throughout the dry season and brought their goats to the communal land to browse shrub pods (huizaches), chickpeas and wheat residues. All farmers, however, had to supplement their goats' feed with concentrates or crop residues. Lactation started in mid-October and the peak of the production was around mid-April. The breeding season started in May when farmers let their bucks mate the does. Milk yields started dropping in July and August (Figure 5).

\section{Access to land}

Figure 6 shows a panoramic view of the valley during the rainy season. From the interviews, we learned that the access to natural capital land was becoming difficult. The land counter-reforms of 1992 that established individual property over ejido land affected the way villagers organized their cropping and livestock husbandry. The first problem due to this land tenure change was that there were less crop residues available for goats. Formerly, after the harvest, all crop residues were left for all village livestock to graze freely. 'Now everything has an owner' (farmer, San José de Vargas). Hence, crop residues had a price. Payments in kind (goat kids) were common to allow access to neighbours' crop residues. Farmers might let their goats graze neighbours' crop residues without asking permission. Goat farmers themselves recognized that there was some stigma for 'stealing' crop residues. Furthermore, the land counter-reforms of 1992 allowed external users to lease and purchase land. For example, in San José de Vargas, there was a mine in operation, which occupied a large portion of the communal land. In the vicinity of Los Charcos, a feedlot for up to 10,000 cattle was established. Los Charcos farmers were concerned about the water reservoirs as the feedlot uses water for the animals and also for slaughtering and meat packing. Added to this, the feedlot sewage was discharged in the village canal, and the farmers were very annoyed by pestilent clouds of dust that covered their village since the feedlot started to operate.

\section{Dairy goat farming: markets and margins}

Goats are an important financial capital. Flocks were mostly crossbred goats of dairy breeds, such as Saanen, French Alpine and Toggenburg. The longitudinal survey showed that annual milk yields per head averaged $422 \mathrm{~L}$ (Standard deviation (SD) 106). Milk was sold at farm gate to the cajeta industry. Male goat kids were also sold. They fetch prices of around 270 Mexican pesos (MX\$) (USD 22). Goat kid meat had a seasonal market at 


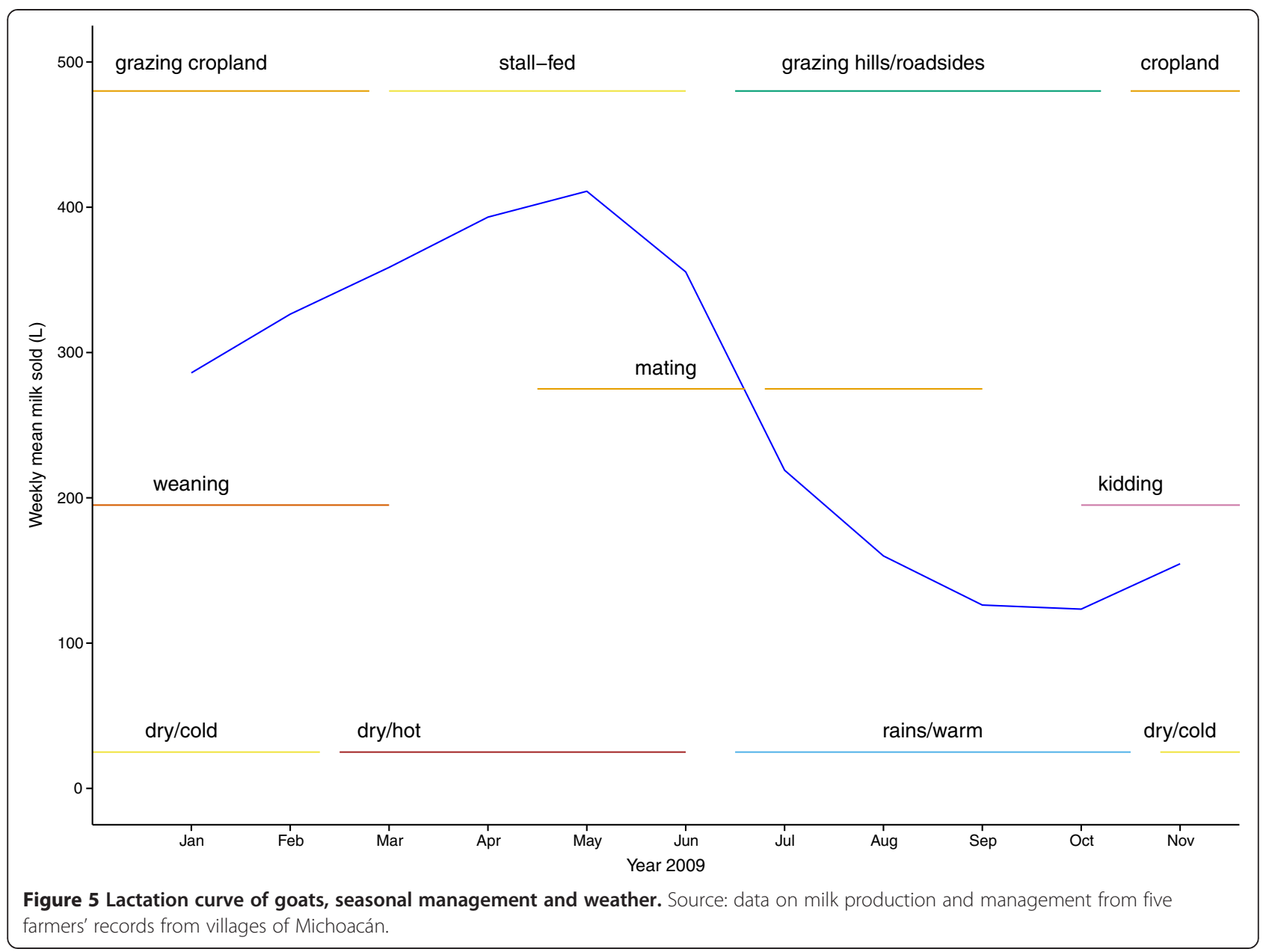

the end of the year (Christmas and New Year celebrations) coinciding also with the return of migrants. The role of goat husbandry as a source of income is shown in Figure 7. Plot A shows the importance of goat milk sales to the total on-farm gross margins (i.e. cropping and goat husbandry). Lower gross margins were obtained by households with small flocks, which belonged to the poor. There was a linear relationship between milk sales and gross margins. Plot B shows that cropping had a lower direct impact on on-farm gross margins than goats. To some extent, goat husbandry had a higher impact on gross margins when compared to cropping (plots A and B) because farmers used their own crops as feed, inputs for cropping were costly and crops failed due to droughts.

Households in the medium and better-off strata obtained larger gross margins when compared to the poor, as shown in Figure 8 (plots A and B). The contribution of goat husbandry and cropping in relation to the poverty line is shown in plot B. The gross margins per capita of poor farmers (median $=4,987, \mathrm{IQ}=3,895$ to 11,948 ) and medium farmers (median $=9,029, \mathrm{IQ}=7,736$ to 11,723 ) were under the poverty line. Only a better-off farmer was well above the poverty line.

The positive gross margins from goat husbandry were a reason for its popularity. For example, in one of the villages (Cieneguitas) where there were formerly three to four goat farmers, there were now 28 households with goat flocks averaging 40 head (SD 36), according to a census done by an NGO. '[T] here are a lot of goats now, the truck used to come for 600 litres, now two trucks leave full of milk ... now everybody has some goats' (farmer, Cieneguitas). Another farmer comparing cattle with goats said that 'cows do not produce, it takes two years before you can sell a calf' (farmer, San José de Vargas).

Farmers' main concern was the milk price though; they received \$MX 4 (USD 0.33) per litre and they felt that the price did not increase at the same rate as input costs. Figure 9 shows how the milk price (adjusted to 2008 prices) fell during 2006 and 2007. In November 2007, the price increased until March 2008 and then started to fall again. The cajeta companies justified their 


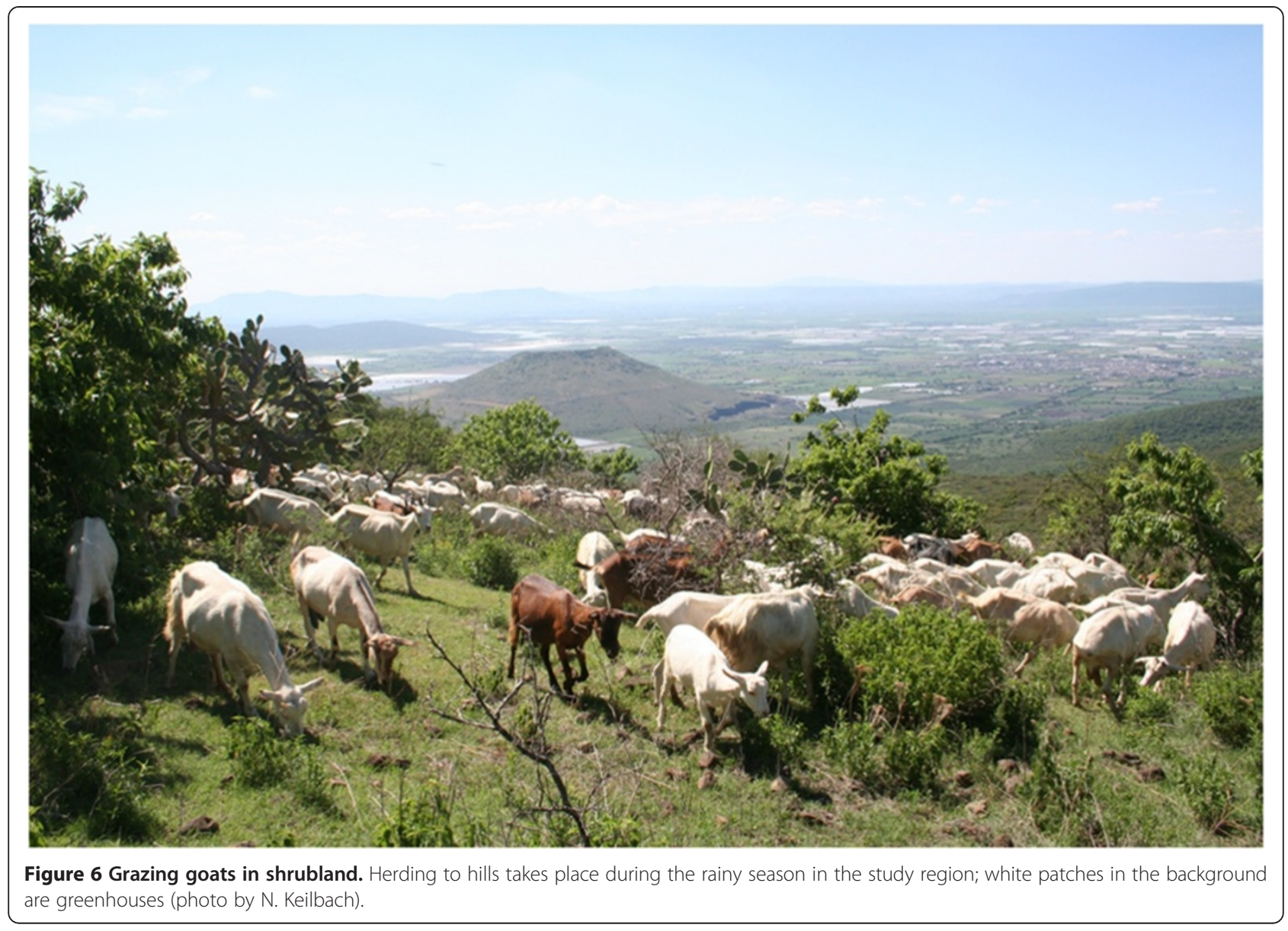

farm gate milk price because farmers produced little milk and milk quality was low. The managers of the cajeta plants claimed that 'they [farmers] produced very little [individually], to fetch the milk at farm gate is very costly... they have very very inefficient systems, they keep many non-productive goats' (managers of the cajeta plants). The leading company in collecting the milk was a multinational company Coronado. There were two other prominent milk companies - Cajeta Cabadas and Real the Potosí. The Coronado plant processed over 12 million litres in 2010. We were informed that there was a $38 \%$ increase in milk processed in 2010 compared to 2008.

The cajeta industry controlled the goat milk market. The managers of cajeta local plants were known as the 'patrón' (the boss) by farmers. To prevent the farmers teaming up to demand a higher milk price, the industry paid a slightly higher price to farmers with larger flocks than to the majority of the farmers, which was a kind of divide et impera strategy. Adding water to milk was sometimes how farmers took revenge for the low price for their milk. They however risked paying a penalty because random samples were taken to detect diluted milk. There were also patronage strategies used by the industry to ensure that a farmer's milk production was sold to them. When goats were dry, farmers asked for credit from milk traders and the industry. In turn, farmers sold their milk to their credit providers. Credits were given without interest rates and were paid back gradually when the milk production was peaking again. Usually these credits were used for daily living expenses and were equivalent to one or two weeks of a household's milk production. If credits were not given to farmers, the industry risked losing their milk supply, because farmers then sold their milk to a competitor.

Selling milk to the industry at relatively low prices was not the only stressor for farmers. Brucellosis, a zoonotic disease (that can be transmitted from goats to humans), was endemic in the region (NGO personnel, personal communication). Milk processing to produce cajeta eliminates the risk of brucellosis for the consumers. The industry interviewees reported that there were no plans to pay premium prices for milk from brucellosis-free flocks. In 56\% of the households surveyed, respondents reported having at least one family member who had contracted brucellosis. Therefore, as a preventive measure, households avoided goat milk consumption. Farmers reported that physicians recommend staying away from dairy goat products as it is a cause of 'fever'. 


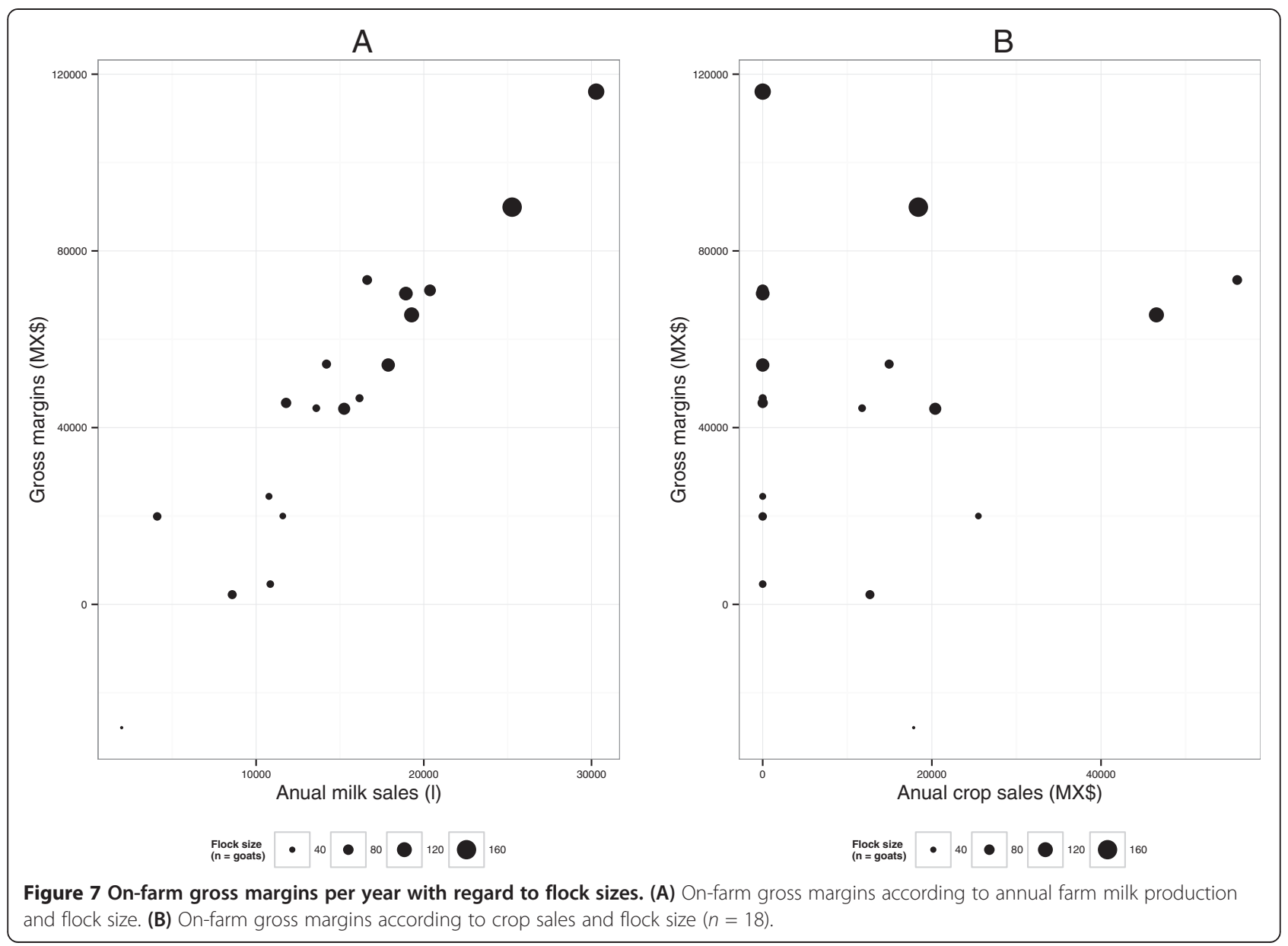

\section{Labour and knowledge}

Goat husbandry involved only family labour. Men took decisions and received the cash from sales of milk. Women took the lead if their husband was ill, or when their husband migrated to the USA. Invariably, men were the herders and daily herding took 6 to 8 hours. If husbands were absent due to migration, boys (some just over 10 years old) could take over the main goat husbandry tasks such as herding. Milking was done by hand once a day in the morning. Women swept the pens after the men left for herding. Usually, one farmer alone was able to milk a flock of up to 70 head. For larger flocks, other family members came to help, such as the chivero wife (Figure 10). Women also helped in washing milk containers, raising goat kids and preparing the menfolk's lunch for herding. In extended households, women and young children helped in other activities like herding and giving medical treatments.

Table 2 shows neighbours' opinions about goat husbandry. Neighbours preferred goat meat over goat dairy products. Goat farmers were seen as 'gente de trabajo' (working people) by their neighbours, which was a compliment. In general, farmers received relatively high esteem among their neighbours. For some farmers, goat husbandry was an apprenticeship for their children. In the villages, the highest school education available was secondary education. Therefore, goat husbandry was attractive for children who could not attend school beyond primary school.

During transect walks, we observed that farmers were skilful in various aspects of goat husbandry such as herding and curing diseases. Farmers used different calls to herd their flocks, such as a call to urge the flock to come back, one to move on or a call to scare a coyote. Farmers also trained village dog pups to become herder dogs to protect flocks against thieves and coyotes. They predicted how long crop residues could last for their flocks and related the quality of crop residues to milk yields, as well as being very familiar with the properties of local vegetation (e.g. toxicity and nutritional value). Their knowledge of the local ecology was also of key importance. Accordingly, they planned routes to herd their flocks to the best spots for feeding. When grazing forage is decaying at the end of the rainy season and scant at the end of dry season, farmers feed their goats homemade rations of grains, forage and concentrates, 


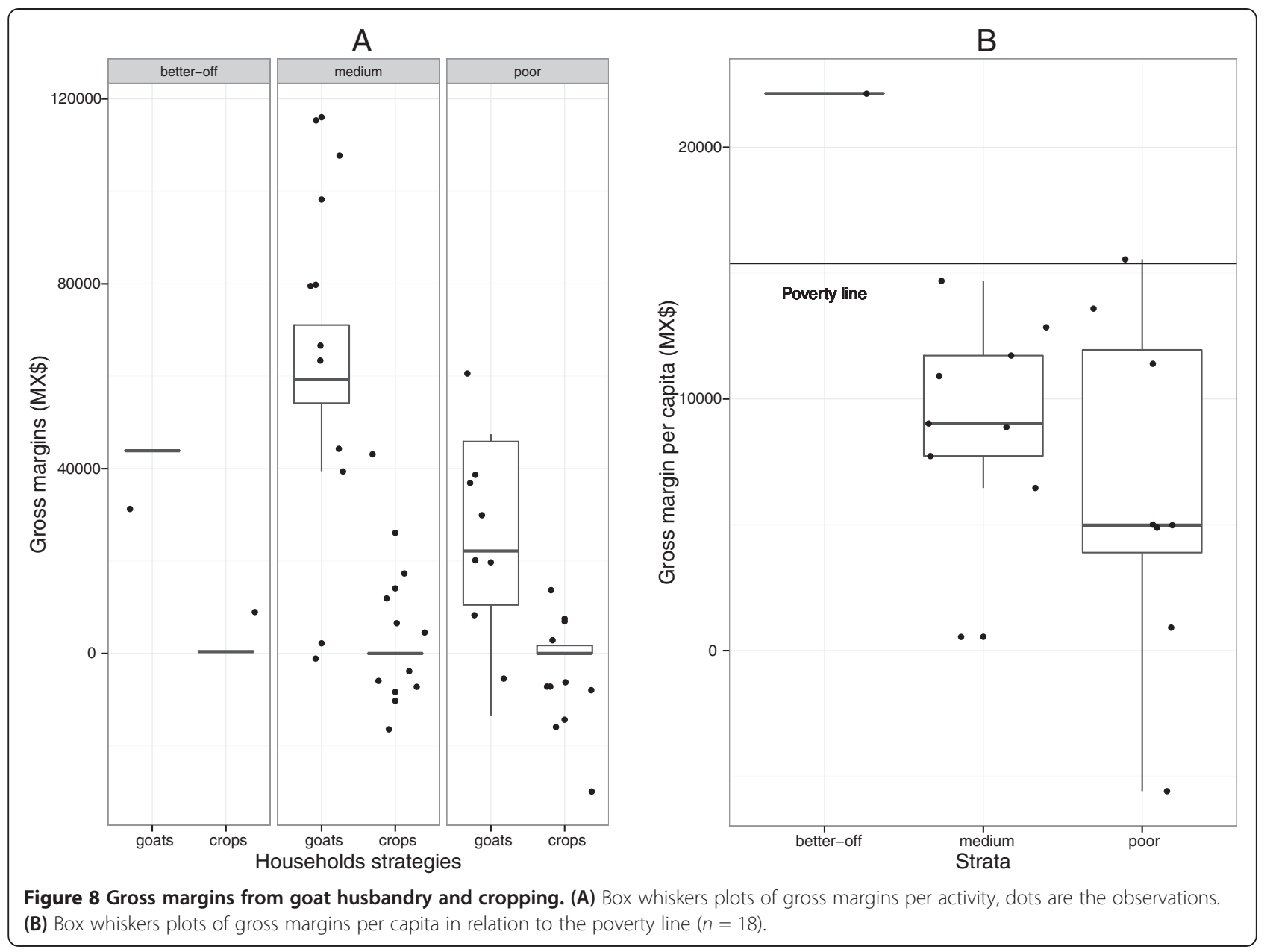

illustrating farmers' knowledge on how to adapt feeding management according to the goats' needs. A common daily ratio per goat was $0.5 \mathrm{~kg}$ of commercial concentrates, maize or sorghum and $0.5 \mathrm{~kg}$ of maize stover or alfalfa. Farmers used natural and local remedies to heal udder cuts and resolve placenta retention. They were also familiar in how to use modern drugs for deworming, vaccinating and curing common infections, such as mastitis, pneumonia and diarrhea. They even knew how to treat acidosis in goat kids, a syndrome known locally as 'borrachito' (drunk syndrome in goat kids), with oral rehydration salts for human use. But farmers perceived that their knowledge was not valued by outsiders. Farmers reported that an employee of the agricultural secretariat referred to them as ignorant and stinky.

\section{Access capitals mediated by institutions}

There was one NGO 'Subcomité de Productores de Ovicaprinos del Estado de Michoacán' (SPOEM) working with goat farmers. This is an exceptional situation with regard to supportive institutions for goat farmers. SPOEM was not initiated within the villages but in the state capital, by an agronomist who envisaged the potential of smallholder farming systems and who intended to go in business with the most prominent goat farmers. The ultimate goal was to produce yoghurt (NGO personnel, personal communication). The entry point to start working with farmers was brucellosis control. The NGO was the channel through which governmental financial support for brucellosis control was given to goat farmers. The activities for brucellosis control included vaccination and testing to detect seropositive goats.

The ambitious brucellosis control programme (free for farmers) seemed to awaken interest from farmers to start goat husbandry and form groups. In some villages, prominent farmers were encouraged to form a group of 10 to 20 farmers and start an extension group GGAVATT (Grupos Ganaderos de Validación y Transferencia de la Tecnología; Livestock farmers groups for technology validation and transfer). Farmers in these groups requested credit to acquire physical capital (e.g. pens).

We were informed that 48 farmers had received credit. We noticed that credit reached the medium and better-off farmers. The project better known as the 'tejabanes project' 


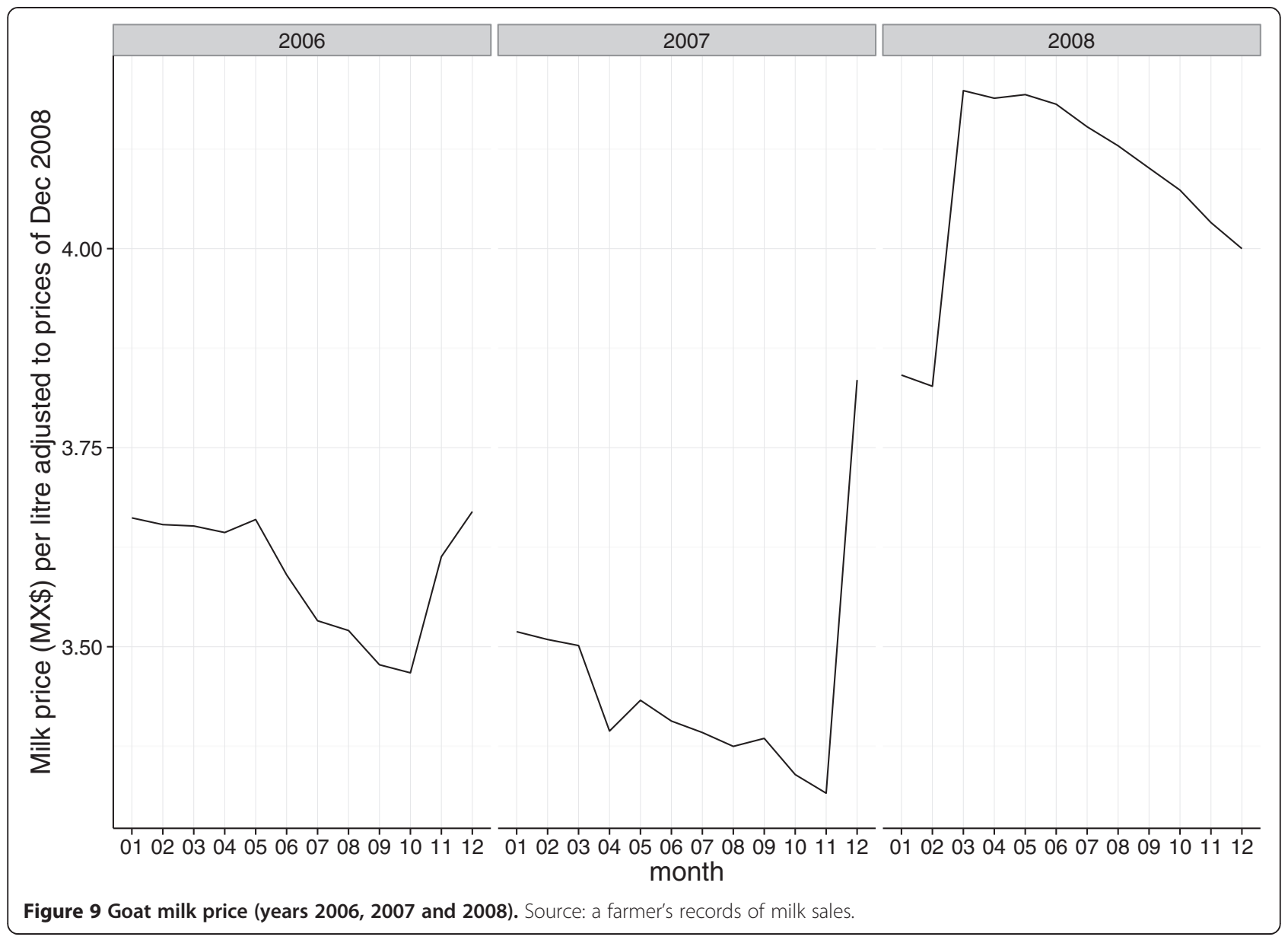

(the pens project) was a kind of 'one size fits all' package of a pen and a milking machine per farmer, a cooling tank per group and also pasteurizers for some farmers. However, many things went wrong. First, pens were stall-fed prototypes, although forage grazing was the main management system. Second, farmers reported that pens were constructed with cheap low-quality materials, differing to the specifications in the original credit plan. One farmer reported having lost his goats when they got trapped and died within the post of the feeding fences, due to the bad design. Doors and fences of the pens were falling apart at the time of the field work. In addition, some better-off farmers already had a good size pen so they ended up having two pens. As a result, some of these pens were later used for other purposes. Figure 11 shows a 'modern' pen acquired through this project which was used to keep fighting cocks instead of goats, while some other farmers used the pens as storage for feed. Other equipment given was obsolete too. The milking machines were rarely used because they ran on petrol or electricity, so they required an extra input. 'We are not paid more for using it so it is not worth it' (farmer, Las Fuentes). The small ramp to milk goats served instead as a bench and table to have lunch, and was not used to milk goats. The cooling tank was placed where there was no electricity (i.e. in Tinaja de Vargas).

Farmers launched a formal accusation of corruption due to the poor quality of the pens and some farmers stopped repaying their credit. In response, the government ceased financial support for the brucellosis campaign when these issues were brought up. Apparently, this was revenge against the NGO for supporting farmers in complaining about governmental corruption. Finally, some farmers who started as a GGAVATT group complained about not receiving any financial support compared to the neighbour village groups. Interviewed farmers reported that they had invested time and money in this group and nothing came of it. In summary, the pens project in Michoacán brought only problems, as one farmer reported.

\section{Discussion}

Goat husbandry is part of the portfolio of smallholders' activities. Diversification has also been described in small-scale goat husbandry in northern parts of the country (Mora-Ledesma 2011). The increasing number 


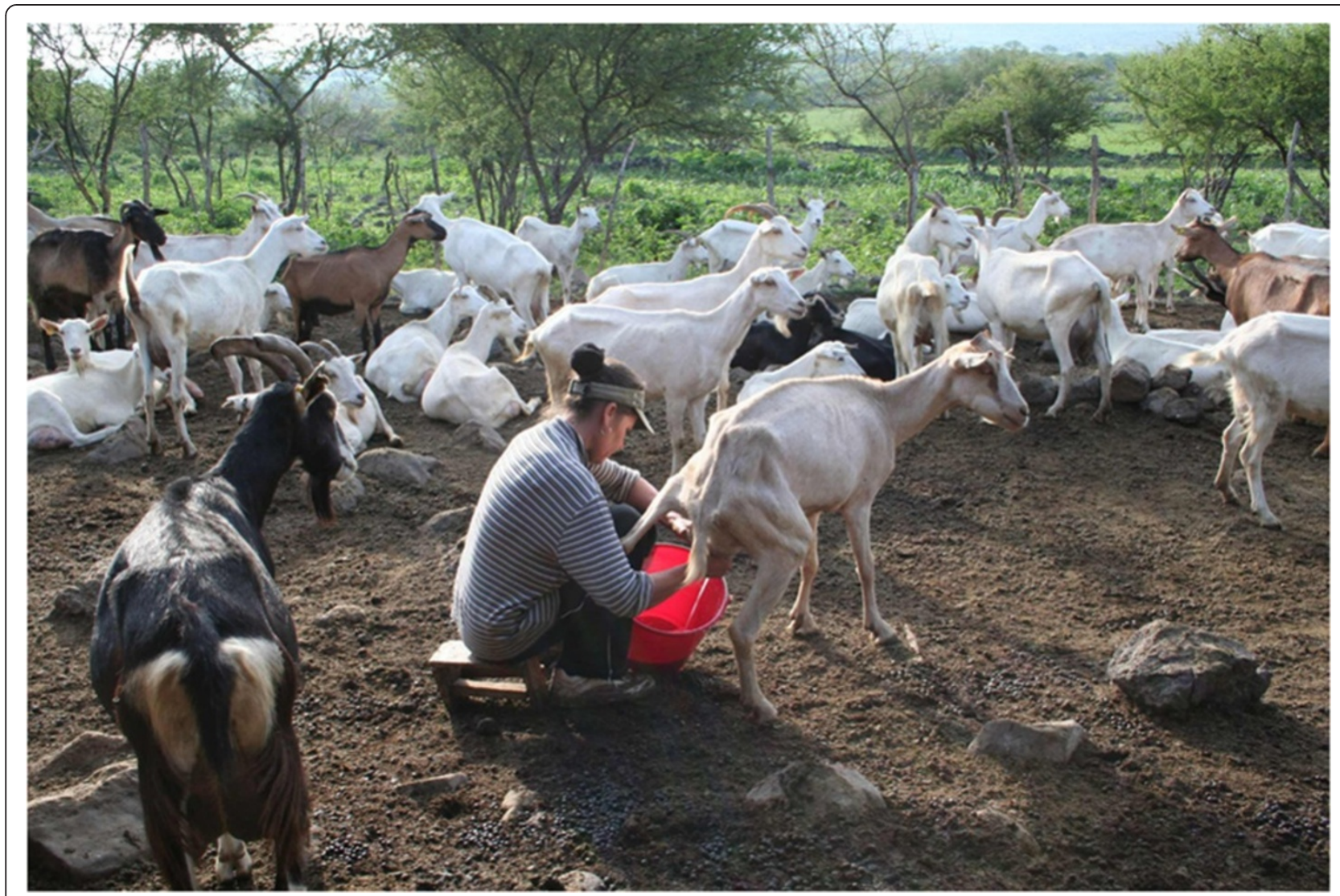

Figure 10 Woman milking a goat flock. Hand milking is predominant even when flocks are large. Tinaja de Vargas, Michoacán (photo by N. Keillbach).

of households involved in goat keeping in various villages indicates that there is a growing interest among smallholders. Goat milk has become an important commercial commodity, while crops are mainly used for home consumption and as feed for the goats. Commercial cropping has become a risky activity for smallholders, whereas goat husbandry is relatively more feasible, especially for those having little or no land. As sale of milk gives a regular income, farmers try to optimize their income sources and manage risks through goat husbandry. This shows also farmers' agency; even among the poor, taking an active role to make their living a sustainable livelihood as they pursue autonomy and self-sufficiency. Goat husbandry seems to support those who argue that smallholders should not disappear, the so-called campesinistas (peasantists) (Kay 2008).

We have shown that smallholders have a rich knowledge on keeping goats; this is very different to how industry managers and bureaucrats portray a chivero. Mastering a pastoral system in a relatively harsh environment is something to be recognized (Krätli and Schareika 2010). This type of knowledge is described in Africa (e.g. Oba 2012) and in other parts of Mexico (Mora-Ledesma 2011). There is a rich goat husbandry knowledge transmitted through generations; part of this traditional knowledge originated during the Spanish colonial period around 500 years ago. The smallholder farming systems have subsisted all these years and are quite efficient, given the small size of cropland properties. Smallholders make use of the abundantly available natural capital, the so-called 'unproductive' shrub land.

Social capital is a key factor in goat husbandry, represented in community companionship, trust and the family members' work on various tasks of keeping a flock. A main drawback for smallholder goat farming was a weak community social capital due to violent events. Violence is increasing in the whole country, and in Michoacán, it is especially disturbing as murders were $100 \%$ higher in 2009 than in 2006 (INEGI 2014). Although the analysis of this violent environment goes beyond the scope of this paper, it is an example of the consequences of livelihood destruction in Mexico's rural villages. As we were informed, farmers flee and stop farming, in order to avoid violence in one of the villages.

Our aim was also to understand the role of goats in improving poor people's livelihoods. This was done by investigating the role of goat husbandry among three groups of farmers defined as 'poor', 'medium' and 
Table 2 The opinions of farmers' neighbours about goat husbandry $(n=145)$

\begin{tabular}{|c|c|c|c|c|}
\hline & \multicolumn{4}{|l|}{ Villages } \\
\hline & Cineguitas & Los Charcos & San José de Vargas & Tinaja de Vargas \\
\hline Number of respondents $(n)$ & 37 & 59 & 27 & 22 \\
\hline \multicolumn{5}{|l|}{ Low esteem to goat farmers (\%) } \\
\hline Destructive & 3 & 4 & 15 & 0 \\
\hline Odour & 0 & 15 & 4 & 0 \\
\hline \multicolumn{5}{|c|}{ High and neutral esteem to goat farmers (\%) } \\
\hline Working people & 16 & 17 & 11 & 14 \\
\hline Generate employment & 3 & 9 & 18 & 45 \\
\hline Good but no specific reason & 8 & 2 & 4 & 0 \\
\hline Neutral & 70 & 53 & 48 & 41 \\
\hline \multicolumn{5}{|l|}{ Dislikes about goats (\%) } \\
\hline Nothing & 68 & 37 & 56 & 77 \\
\hline Smell & 27 & 43 & 22 & 23 \\
\hline Smell combined with flies & 5 & 20 & 22 & 0 \\
\hline \multicolumn{5}{|l|}{ Likes about goats (\%) } \\
\hline Nothing & 11 & 13 & 19 & 14 \\
\hline Dairy product & 5 & 5 & 0 & 5 \\
\hline Meat & 84 & 70 & 74 & 73 \\
\hline Meat and dairy & 0 & 12 & 7 & 9 \\
\hline
\end{tabular}

'better-off'. Farmers said that in general, having goats was better than not having goats. For poor households, goat husbandry was more vital than for the medium and better-off. The last two groups had a wider range of activities. However, the role of goat husbandry to overcome the poverty line (i.e. fulfill basic necessities) is far from ideal. Most households were not earning enough per capita to overcome the poverty line of MX\$ 15,348 per year (the equivalent of approximately US\$ 1,250). Flock size is a factor in the overall on-farm gross margins (i.e. crops and goats). Poor farmers would need to own at least 30 adult dairy goats per capita to move to the medium group. We met cases of young couples in the poor category with relatively small flocks (approximately 15) where men were eager to migrate to the USA. Farmers in middle and better-off groups cultivated more land and of higher crop potential. Therefore they have more feed for their flocks. The poor have to restrain their flock size because they lack their own feed sources and have to buy extra feed. Therefore, claiming that goats can let people step out of poverty is not as straightforward as suggested in some articles (Peacock 2005; De Vries 2008).

It would have been useful to have more precise information about other cash resources, i.e. remittances and off-farm jobs. But it was very difficult to gain farmers' trust in mentioning money flows. Farmers found it rather strange that an outsider wanted to investigate their livelihoods. Farmers also found it hard to understand the overall benefits of our research, which were not tangible and were to some extent long term, so we did not want to risk stretching their confidence to the limit.

We did also meet two extended households that managed to keep relatively large flocks $\geq 400$ goats (33 goats per capita), which allow them to acquire land. There were at least three key capitals for these extended families in their process of consolidation. First, there was a good individual social capital (i.e. family cooperation), second, human capital (i.e. labour of two or three generations including women and children) and natural capital (i.e. shrub land and village crop land residues). Poor households owned small plots (1 to $2.5 \mathrm{ha}$ ) and due to lack of financial resources and male labour because of USA migration, they could not cultivate their plots. Farmers with little crop land can however have access to crop residues of neighbours and access to communal grazing land to feed their flocks. But the land counter-reforms of 1992 threaten the access to these resources.

The neoliberal administrations tend to favour large farm operations (e.g. a feedlot) and mining. This is leading to resource exploitation of vast land areas by powerful companies. The potential of new conflicts due to delimiting access and creating competition for resources is just around the corner, as occurs elsewhere (Hollander 2013). An example in Mexico is the experience with mines: local communities do not get what they are promised, while 


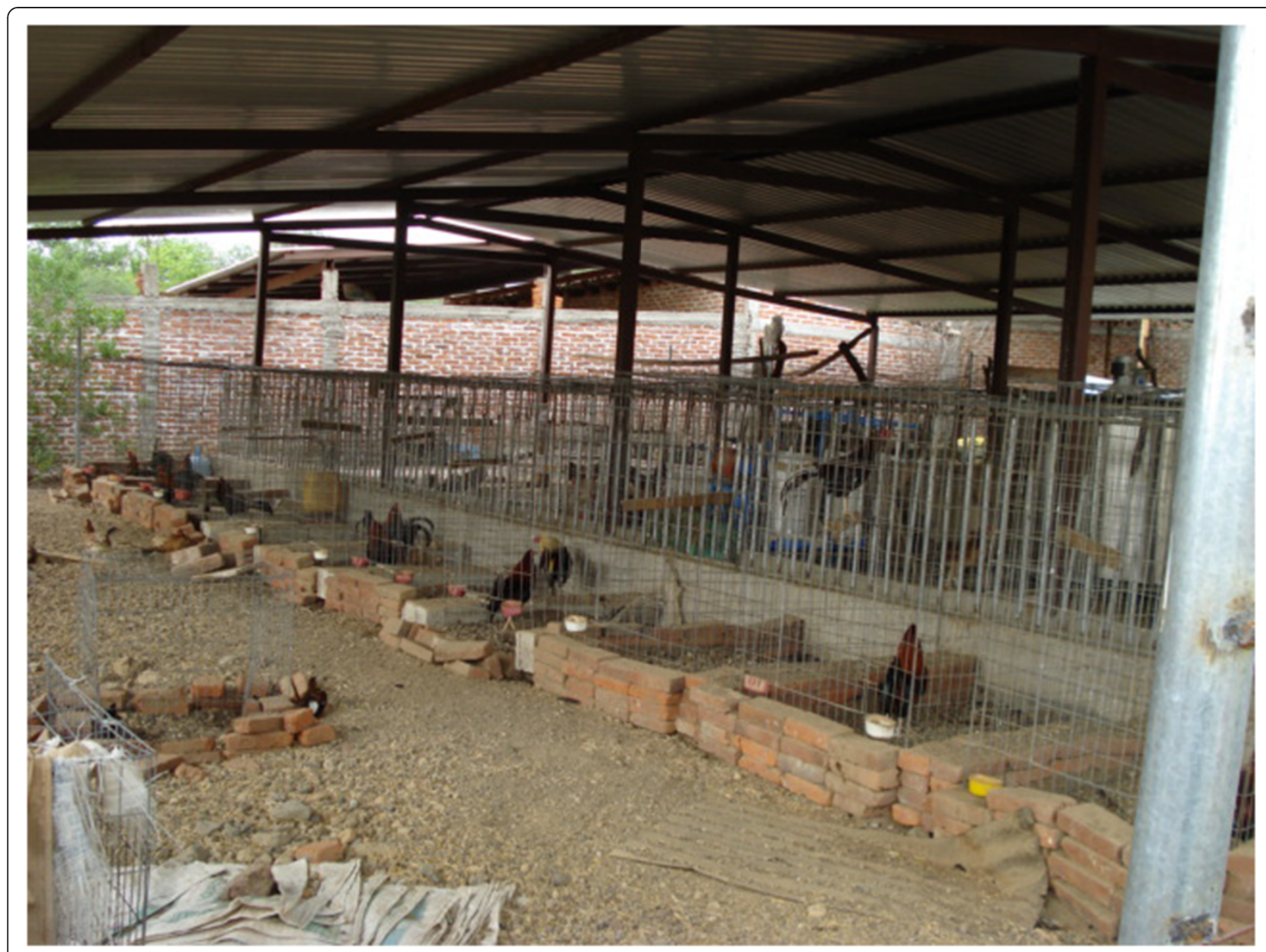

Figure 11 A 'modern' goat pen is used to keep fighting cocks. Michoacán, Mexico (photo by D. Oseguera).

mines restrict access to communal grazing land and also pollute air, soil and water (Rodríguez Wallenius 2011). Similarly, the feedlot enterprise in the vicinity of one of the villages is polluting air and water sources.

Goat milk is a commodity that generates a regular income flow for households; however, the milk trade is disadvantageous for farmers. A similar disadvantageous dairy marketing has been described in northern parts of the country (Gómez-Ruiz et al. 2012). There was a huge contrast between the farmers' uneasy economic situation and the prosperous cajeta industry. Coronado is a subsidiary of Bimbo, worldwide the fourth largest food company and the largest bread manufacturer (Ochoa 2013). Bimbo reported 20\% larger profits in 2005 than in 2004. ${ }^{\text {a }}$ Farmers were paid about $13 \%$ of the shelf price. ${ }^{\mathrm{b}}$ The caramel industry is the main winner here and as such it can be called a 'food empire' (Ploeg 2010), which sets its rules such as milk price and the quality standards, e.g. checking watered milk, that are important for cajeta production.

Farmers' main concern is the milk price which is stagnant in relation to inflation and to prices of their inputs. The goat milk market is in a vicious cycle where milk price is low and therefore the milk hygiene quality is low. Brucellosis, a zoonosis endemic in goat flocks of the region (Oseguera Montiel et al. 2013), does not receive enough attention. This is not an issue in the eyes of the cajeta industry. Given the current circumstances, the risk of getting brucellosis is carried only by farmers' families. This is detrimental to farmers' livelihoods because affected individuals are not able to work and may develop permanent disabilities, e.g. arthritis, spondylitis (Corbel 2006). Furthermore, brucellosis in goats is responsible for losses due to abortion and hence milk production is reduced (Corbel 2006).

Controlling brucellosis could be an opportunity for farmers to find a niche market for a high-quality dairy product. Currently, such a market is exploited by a relatively small group of goat farmers approximately $20 \mathrm{~km}$ from the neighbour state of Guanajuato. Farmers might need to team up to achieve a better market. Stories of smallholder crop farmers forming cooperatives can be found elsewhere (King et al. 2012). A cooperative led by 
women may be a way to empower women. Women are mostly involved in milking and cleaning corrals, but they could be playing a key role when goat milk is further processed (e.g. cheese making). Poorer households should be included in such plans too. Farmers' social capital such as cooperation and trust can be a starting point for developing cooperatives with the help of NGOs or governmental institutions. Unfortunately, good institutional support is lacking. Credit given to acquire 'modern' equipment in a 'one size fits all' package indicates the governmental institutions' desire for a modern agriculture sector. However, there was a mismatch between the package designed and the extensive grazing system used by the majority of goat farmers. A programme aiming to improve the pens of all farmers (not only the 'better-off') would have had a higher impact than the 'Proyecto de los tejabanes'. The project only reached a really small fraction of the goat farmers of the region. In the whole state, there are 11,281 goat farmers (INEGI 2007).

\section{Conclusions}

Goat husbandry in the Bajío, Mexico, is embedded in a complex context influenced by neoliberal policies that do not favour the small-scale farming sector. However, goat husbandry has a growing interest among farmers, partly because cropping has become risky and less profitable. Farmers see goats as a source of income, security, credit, prestige, independence, food, manure and apprenticeship for young children. The interest is present among all socio-economic strata. For the poor, goat husbandry was one of the main livelihood strategies. Better-off and medium group households had a wider range of activities. Wealthier farmers had relatively larger flocks and higher gross margins from goat husbandry than poor households. There were households who strengthened other capitals and strategies through goat husbandry. But these are just a handful of stories. The potential of goat husbandry as a tool for poverty alleviation is not visible yet. A dairy market oligopoly is a main drawback. This is partly linked to brucellosis in flocks, because the industry does not pay for high-quality milk; hence, there is no interest in tackling the brucellosis problem. Farmers are powerless against the dairy industry. There are opportunities for a better dairy market if brucellosis could be eradicated from the flocks. This could also reduce the risk of brucellosis in humans. Natural capital (i.e. communal grazing land) is key in goat husbandry. Historically, goat husbandry has persisted because of the abundance of this 'unproductive' land. Powerful external organizations have interests in this land and are therefore a threat for smallholder goat husbandry. Given the relatively low amount of crop land available for each household, we have shown that small-scale goat husbandry is productive, in contrast to the dominant discourse that smallholder goat husbandry systems are 'unproductive'.

\section{Endnotes}

${ }^{a}$ EMBITDA (earnings before interest, taxes, depreciation and amortization) were MX\$ 7,191 million (Bimbo 2005).

${ }^{\mathrm{b}} \mathrm{A}$ jar of $660 \mathrm{~g}$ of cajeta Coronado was MX\$ 61 (PROFECO 2012). Cajeta main inputs are milk and sugar; for $660 \mathrm{~g}$ of cajeta about $2 \mathrm{~L}$ of milk and $660 \mathrm{~g}$ of sugar are needed (employee, personal communication).

\section{Competing interests}

The authors declare that they have no competing interests.

\section{Authors' contributions}

DOM conceived the study, carried out the field work, analysed the data and drafted the manuscript. NMK assessed the field work, HK, AJZ, NMK and CS commented on the manuscript. All authors read and approved the final manuscript.

\section{Acknowledgements}

Foundation Alfa and Omega in the Netherlands and The National Council for Science and Technology in Mexico (CONACYT) sponsored the first author and generously funded this research. We thank all farmers for their participation and hospitality during the field work. The authors wish to thank Dr. Anne Pearson for editing the manuscript and for valuable suggestions and comments with content of the manuscript. We also wish to thank Marco Antonio Hernández Andrade for his help in producing the map (Figure 1). Finally, we are thankful for the comments of an anonymous reviewer and to Carol Kerven for kindly editing the manuscript. The usual disclaimers apply.

\section{Author details}

${ }^{1}$ Animal Production Systems Group, Wageningen University, P.O. Box 338 Wageningen $6700 \mathrm{AH}$, the Netherlands. ${ }^{2}$ Colegio de Michoacán A.C., Martínez de Navarrete 505, Col. Las Fuentes, Zamora, Michoacán 59699, Mexico. ${ }^{3}$ Sociology of Consumers and Households Group, Wageningen University, P.O. Box 8060, Wageningen 6700 DA, the Netherlands.

Received: 13 February 2014 Accepted: 9 June 2014

Published online: 10 July 2014

\section{References}

Arias, P, and G Mummert. 1987. Familia, mercados de trabajo y migración en el centro-occidente de México. Nueva Antropología. Revista de Ciencias Sociales 9: 105-128.

Banixco. 2012. Banco de México: Serie histórica del tipo de cambio peso-dólar. http://www.banxico.org.mx. Accessed 27 August 2012.

Baroni-Boissonas, A. 1990. La formación de la estructuraagraria en el Bajío colonial. Siglos XVI y XVII. México, D.F: SEP Setentas, Ediciones. Centro de Investigaciones y EstudiosSuperiores en Antropología Social.

Bebbington, A. 1999. Capitals and capabilities: a framework for analyzing peasant viability, rural livelihoods and poverty. World Development 27: 2021-2044. doi:10.1016/S0305-750X(99)00104-7.

Biernacki, P, and D Waldorf. 1981. Snowball sampling. Sociological Methods and Research 10: 141-163. doi:10.1177/004912418101000205.

Bimbo. 2005. Bimbo 60 years, still growing heatlhier and stronger. Annual report 2005. http://www.mzweb.com.br/grupobimbo/web/arquivos/ GrupoBimbo_IIAR_2005_eng.pdf. Accessed 15012014

Bosman, HG, HAJ Moll, and HMJ Udo. 1997. Measuring and interpreting the benefits of goat keeping in tropical farm systems. Agricultural Systems 53: 349-372. doi:10.1016/S0308-521X(96)00047-9.

Braudel, F. 1984. Civilización material, economía y capitalismo, siglos XV-XVIII, vol. I. Madrid: Alianza

Budisatria, IGS. 2006. Dynamics of small ruminant development in Central Java-Indonesia, PhD thesis. Wageningen: Wageningen University.

Chambers, R, and GR Conway. 1992. Sustainable rural livelihoods: practical concepts for the 21 st century. Technical report, Institute of Development Studies. https:/www. ids.ac.uk/files/Dp296.pdf.

Chambers, KJ, SB Brush, MN Grote, and P Gepts. 2007. Describing maize (Zea mays L.) landrace persistence in the Bajío of Mexico: a survey of 1940s 
and 1950s collection locations. Economic Botany 6(1): 60-72. doi:10.1663/ 0013-0001(2007)61[60:DMZMLL]2.0.CO;2.

Chávez-Torres, M. 2005. Bajío, Bajíos: Unidadesterritoriales de unaregión. Regiones: revistainterdisciplinaria en estudiosregionales 15: 117-140.

CONEVAL. 2009. Consejonacional para la evaluación de la política de desarrollo social- reportaconevalcifra de pobrezaporingresos 2008. http://www.coneval. gob.mx/Paginas/principal.aspx. Accessed 14 January 2014.

Corbel, MJ. 2006. Brucellosis in humans and animals. Geneva: World Health Organization.

de Haan, L. 2000. Globalization, localization and sustainable livelihood. Sociologia Ruralis 40: 339-365. doi:10.1111/1467-9523.00152.

de Haan, L, and A Zoomers. 2005. Exploring the frontier of livelihoods research. Development and Change 36(27-47): 2005. doi:10.1111/j.0012155X.2005.00401.X.

de Vries, J. 2008. Goats for the poor: some keys to successful promotion of goat production among the poor. Small Ruminant Research 77: 221-224. doi:10.1016/j.smallrumres.2008.03.006

DFID. 1999. Sustainable livelihoods guidance sheets. Technical report, Department for International Development. http://www.eldis.org/go/ home\&id=41731\&type=Document\#.U7BqQ_mSySp. Accessed 21-May-2012.

Dossa, LH, B Rischkowsky, R Birner, and C Wollny. 2008. Socio-economic determinants of keeping goats and sheep by rural people in southern Benin. Agriculture and Human Values 25: 581-592. doi:10.1007/s10460-008-9138-9.

Ellis, F. 2000. Rural livelihoods and diversity in developing countries. New York: Oxford University Press.

Fenton, A. 2006. Weft QDA (version 1.0.1) computer software. http://www. pressure.to/qda/.

Gómez-Ruiz, WJ, JM Pinos-Rodríguez, JR Aguirre-Rivera, and JC García-López. 2012. Analysis of a goat milk cheese industry in a desert rangeland of Mexico. Pastoralism: Research, Policy and Practice 2: 1-11.

González-Martínez, L. 1992. Respuesta Campesina a la Revolución Verde en el Bajío. México D.F.: Universidad Iberoamericana.

Hollander, S. 2013. The tragedy of the deprived. http://www.thebrokeronline.eu. Accessed 7 November 2013.

INEGI. 2007. Censo agrícola, ganadero y forestal. http://www.inegi.org.mx. Accessed 16 January 2014

INEGI. 2011. Conjunto de datos vectoriales de uso de suelo y vegetación. http://www.inegi.org.mx/geo/contenidos/recnat/usosuelo/inf_e1 m.aspx. Accessed 30 May 2014.

INEGI. 2014. Registros administrativos: defunciones por homicidio. http://www inegi.org.mx. Accessed on 15(January 2014).

Kay, C. 2008. Reflections on Latin American rural studies in the neoliberal globalization period: a new rurality? Development and Change 39: 915-943. doi:10.1111/j.1467-7660.2008.00518.x.

King, R, MA Adler, and M Grieves. 2012. Cooperatives as sustainable livelihood strategies in rural Mexico. Bulletin of Latin American Research 32: 166-177. doi:10.1111/j.1470-9856.2012.00796.x.

Krätli, S, and N Schareika. 2010. Living off uncertainty: the intelligent animal production of dryland pastoralists. European Journal of Development Research 22: 605-622. doi:10.1057/ejdr.2010.41.

Kristjanson, P, A Krishna, M Radeny, J Kuan, G Quilca, A Sanchez-Urrelo, and C Leon-Velarde. 2007. Poverty dynamics and the role of livestock in the Peruvian Andes. Agricultural Systems 94: 294-308. doi:10.1016/.agsy.2006.09.009.

Long, Norman. 1998. Cambio rural, neoliberalismo y mercantilización. In Las Disputas por el México rural: Actores y campesinos sociales, ed. Zandejas Sergio and Pieter de Vries, 45-71. Zamora: El Colegio de Michoacán AC.

Mora Ledesma, MI. 2011. Vámonos con todo y chivas. Revista del Colegio de San Luis 1: 49-68.

Morand-Fehr, P. 2005. Recent developments in goat nutrition and application: A review. Small Ruminant Research 60: 25-43. doi:10.1016/j. smallrumres.2005.06.004

Oba, G. 2012. Harnessing pastoralists' indigenous knowledge for rangeland management: three African case studies. Pastoralism: Research, Policy and Practice 2: 1-25. doi:10.1186/2041-7136-2-1.

Ochoa, CE. 2013. Feast and famine: The growth of corporate wealth and food insecurity in neoliberal Mexico. Food Sovereignty: A Critical Dialogue. International Conference Yale University. Paper No. 14. http///mww.iss.n//research/research_programmes/ political_economy_of_resources_environment_and_population_per/networks/ critical_agrarian_studies_icas/food_sovereignty_a_critical_dialogue/.

Oseguera Montiel, D, K Frakena, HMJ Udo, NM Keilbach Baer, and AJ van der Zijpp. 2013. Prevalence and risk factors for brucellosis in goats in areas of
Mexico with and without brucellosis control campaign. Tropical Animal Health and Production 45: 1383-1389. doi:10.1007/s11250-013-0375-6.

Peacock, C. 2005. Goats-a pathway out of poverty. Small Ruminant Research 60 179-186. doi:10.1016/j.smallrumres.2005.06.011.

Pereyra, G. 2012. México: violencia criminal y "guerra contra el narcotráfico". Revista Mexicana de Sociología 74: 429-460.

PROFECO. 2012. Procuraduría federal del consumidor. http://www.profeco.gob. $\mathrm{mx} /$ precios/canasta/default.aspx. Accessed 28 August 2012.

R Core Team. 2012. R: A Language and Environment for Statistical Computing. Vienna, Austria: R Foundation for Statistical Computing. http://www.R-project.org/.

Rabell, CA. 1986. Los diezmos de San Luis de la Paz. México, D.F.: Instituto de Investigaciones Sociales, Universidad Nacional Autónoma de México.

RAN. 2010. (RegistroAgrarioNacional) Padrón e historial de núcleosagrarios. http://www.ran.gob.mx/ran/index.php/nuestros-sistemas/padron-historico-phina. Accessed 14 December 2011.

Rodríguez Wallenius, CA. 2011. Dominio del terreno campesino por mineras canadienses 2011. La Jornada del Campo: Newspaper reportage. No 4. 15-January.

Schmidt, RH, and WC Gruben. 1992. Ejido Reform and the NAFTA. Federal Reserve Bank of San Francisco: Economic Letter 92. http://www.frbsf.org/ publications/economics/letter/1992/el92-34.pdf.

Scoones, I. 2009. Livelihoods perspectives and rural development. Journal of Peasant Studies 36: 171-196. doi:10.1080/03066150902820503.

Sinn, R, J Ketzis, and T Chen. 1999. The role of woman in the sheep and goat sector. Small Ruminant Research 34: 259-269. doi:10.1016/S0921-4488(99) 00078-4.

Toledo, V. 1992. Utopía y naturaleza. El nuevo movimiento ecológico de los campesinos e indígenas de América Latina. Nueva Sociedad 122: 72-85. 1992.

van der Ploeg, JD. 2010. Nuevos campesinos: Campesinos e imperios alimentarios. Barcelona: Icaria Editorial.

Wickham, H. 2009. ggplot2: elegant graphics for data analysis. New York: Springer. http://had.co.nz/ggplot2/book.

Zendejas Romero, JS. 2003. Política local y formación del estado: procesos históricos de formación de espacios y sujetos sociales en un municipio rural Mexicano, 1914-1998, PhD thesis. Wageningen: Wageningen University.

doi:10.1186/s13570-014-0009-2

Cite this article as: Oseguera Montiel et al: 'It is better to herd than be herded': making a living with goats in the Bajío region, Mexico. Pastoralism: Research, Policy and Practice 2014 4:9.

\section{Submit your manuscript to a SpringerOpen ${ }^{\odot}$ journal and benefit from:}

- Convenient online submission

- Rigorous peer review

- Immediate publication on acceptance

- Open access: articles freely available online

- High visibility within the field

- Retaining the copyright to your article

Submit your next manuscript at $\gg$ springeropen.com 